\title{
MERCANTILIZAÇÃO DO LAZER NO BRASIL
}

Recebido em: 01/07/2017

Aceito em: 20/03/2018

\author{
Cleber Dias ${ }^{1}$ \\ Universidade Federal de Minas Gerais \\ Belo Horizonte - MG - Brasil
}

RESUMO: Este artigo apresenta uma reflexão sobre o desenvolvimento histórico do processo de mercantilização do lazer no Brasil. A mercantilização é apontada aqui como um dos aspectos mais importantes para a emergência histórica do lazer. Além disso, o artigo sustenta que a mercantilização do lazer se deu antes da década de 1960, período que geralmente é apontado como marco cronológico desse processo. Mais que isso, todo o longo processo de desenvolvimento histórico do lazer no Brasil anterior à década de 1960 foi determinante para os rumos e os formatos da mercantilização do lazer no país.

PALAVRAS CHAVE: História. Atividades de Lazer. Mercantilização. Brasil.

\section{COMMERCIALIZATION OF THE LEISURE IN BRAZIL}

ABSTRACT: This article presents a meditation about the historical development of the commercialization of leisure in Brazil. The commercialization has been pointed here as one of the most important aspects for the historical rising of the leisure. In addition, the article support that the commercialization of the leisure in Brazil happened before the decade of 1960, time usually indicated as chronological mark for this process. More important, all this long historical development process of the leisure in Brazil before the decade of 1960 was determinant to the ways and the format of the commercialization of the leisure in the country.

KEYWORDS: History. Leisure Activities. Commodification. Brazil.

A bibliografia brasileira especializada consolidou a noção de que o desenvolvimento empresarial da cultura ocorreu a partir da segunda metade do século 20, mais precisamente a partir da década de 1960. Segundo o sociólogo Renato Ortiz (1994), talvez um dos primeiros a articular teoricamente esta compreensão, "a

\footnotetext{
${ }^{1}$ Doutor em Educação Física. Professor do Programa de Pós-Graduação Interdisciplinar em Estudos do Lazer da Universidade Federal de Minas Gerais (UFMG).
} 
consolidação de um mercado cultural somente se dá entre nós [brasileiros] a partir de meados dos anos 60" (p. 8).

De fato, a comercialização de bens culturais em larga escala no Brasil ganhou novo impulso a partir dessa época. A rigor, é este o período em que surge no país uma economia e uma sociedade verdadeiramente de massas, caracterizada pela comercialização de bens e serviços em larga escala (MELLO; NOVAIS, 1998; PRADO, EARP, 2003). A própria dinâmica comercial ao redor da cultura fornece vários dados nesse sentido. O número de emissoras de rádio quase triplicou num curto período de seis anos, saltando de 106 em 1944, para 300 em 1950. No mesmo sentido, antes de 1946, nenhum jornal diário ou revista semanal alcançava tiragem superior a 200 mil exemplares. Em 1948, a revista O Cruzeiro, publicação semanal de variedades, alcançou tiragem de 300 mil exemplares, número que atingiu o patamar de 550 mil exemplares em 1952. O número de aparelhos de televisão comercializados também cresceu nessa época: de 3.500 em 1951, para 434.000 em 1959 (ORTIZ, 1994). A escala destes mercados só faria intensificar-se nos anos seguintes.

Em novo contexto estrutural, marcado por uma crescente industrialização e urbanização, se intensificaram processos de comercialização de diferentes produtos e serviços. No âmbito da cultura, cinema, rádio, televisão, imprensa, teatro, música e esportes seriam algumas das cadeias produtivas mais obviamente inseridas nesse processo. O número de livros produzidos no Brasil saltou de aproximadamente 43 milhões em 1966, para mais de 245 milhões em 1980. O mercado de revistas, do mesmo modo, saiu de um patamar de 104 milhões de exemplares em 1960, para 500 milhões de exemplares em 1985. O percentual de domicílios brasileiros com aparelhos de televisão aumentou de $56 \%$ em 1970, para $73 \%$ em 1982. No mercado fonográfico, no mesmo 
sentido, a venda de toca-discos cresceu 813\% entre 1967 e 1980 (ORTIZ, 1994). Políticas econômicas do período, que estimularam crescimento acelerado e socialmente concentrado, privilegiando as classes mais ricas, potencializaram o alcance dessa industrialização da cultura, dado que o fortalecimento das classes médias, nesse contexto, aumentou a massa potencial de consumidores para produtos de luxo relacionados ao lazer e a cultura.

No entanto, bem antes disso, já se tem indícios de um processo difuso e certamente ainda modesto de comercialização de bens culturais. Ao menos desde os fins do período colonial, mais precisamente a partir da segunda metade do século 18 , há registros de formas relativamente bem estruturadas de comercialização cultural, com proporções e abrangência menores do que aquelas registradas na segunda metade do século 20, certamente, mas nem por isso desprezíveis. Sob o influxo do chamado "reformismo ilustrado", todo o Império Português sofreu uma ampla reforma políticoadministrativa. Na segunda metade do século 18, depois de uma persistente crise econômica ao longo de quase todo aquele século, iniciou-se uma significativa recuperação. $^{2}$

Entre os principais fatores responsáveis por essa recuperação econômica, destaca-se a expansão da indústria têxtil, sobretudo na Inglaterra, o que gerava novas demandas de matérias-primas. Mais ou menos na época, houve interrupção do fornecimento de algodão por parte da principal fonte dos mercados ingleses, que era os Estados Unidos, em razão da guerra entre os dois países iniciada em 1777 e que

\footnotetext{
${ }^{2}$ Essa crise econômica teria sido fundamentalmente resultado de duas guerras com a Espanha por limites de fronteira em suas possessões na América; do incêndio de Lisboa (1750), que destruiu quase toda a cidade e exigiu grandes investimentos na sua reconstrução; do declínio da produção do ouro no Brasil (mais notável depois de 1755); da queda do preço internacional da cana de açúcar, que era um produto importante nas exportações brasileiras do período; além do alto custo dos escravos, tão indispensáveis para o trabalho nas lavouras brasileiras, da onde já se extraíam importantes receitas para os cofres portugueses.
} 
culminaria com a independência norte-americana. Finalmente, a revolução francesa em 1789 praticamente exclui a ilha de Saint-Domingue (atual Haiti) do mercado internacional de açúcar, até então o principal produtor desta matéria-prima, o que abriu oportunidades comerciais para outros país, incluindo o Brasil. Tudo isso, em conjunto, criou um cenário internacional economicamente favorável aos produtos agrícolas produzidos no Brasil e comercializados por Portugal. Como resultado, o período entre 1796 e 1806 pode ser apontado como uma "idade de ouro do comércio português" (SILVA, 2008, p. 512).

No Brasil, os ambientes urbanos das regiões mais ligadas a rede internacional de comércio experimentaram mais intensamente os efeitos desse surto de desenvolvimento. As regiões de Pernambuco, Bahia, Minas Gerais e Rio de Janeiro, que respondiam por quase $70 \%$ de toda a população brasileira por volta de 1776 , cujo total era estimado em aproximadamente um milhão e meio de pessoas, possuíam uma intensa rede de comércio local. Não sem razão, um observador do período registrou que o comércio era a mais forte coluna de sustentação do Brasil. Esse comércio, baseado, sobretudo, no crédito, ao invés do dinheiro em espécie, vendia sapatos, roupas, relógios, brinquedos, tecidos, ferramentas e comidas, especialmente vinho, azeite, bacalhau, especiarias e cachaça, além dos gêneros de primeira necessidade, como sal, carne, leite, ovos, feijão e farinha de mandioca - usualmente empregada também como meio de trocas comerciais.

A comercialização de muitos desses produtos acontecia frequentemente nas ruas, por meio de vendedores e vendedoras ambulantes, mas também em estruturas permanentes, como quitandas, padarias, tendas, vendas, armarinhos e tabernas (os nomes variavam). No fim do século 18 , o número de vendas em Salvador, que era então uma das cidades mais populosas do Brasil, foi estimado em mais de 250 (GRAHAM, 
2013). No mesmo sentido, entre 1790 e 1800, o número de "cafés" no Rio de Janeiro aumentou de 26 para 40 (ALDEN, 2008, p. 575). Em 1799 se contavam mais de 330 tabernas no Rio de Janeiro (ALGRANTI, 2011). Esses eram os únicos estabelecimentos comerciais autorizados a funcionar até o meio-dia de domingos e dias santos, quando praticamente todos os habitantes das cidades eram liberados do trabalho, o que ampliava as capacidades desses locais funcionarem como pontos de sociabilidade e diversão.

Nesse contexto, também se destacaram, entre outras coisas, novas medidas para regulação das diversões, que inauguravam formas de interdição sobre os comportamentos lúdicos da população, tentando controla-los por meio da divulgação de regras bem determinadas de conduta, ao mesmo tempo em que estimulavam outras formas de diversão, tidas como mais civilizadas. Articulado a esse projeto reformista, dos meados do século 18 até os princípios do século 19, "casas de ópera" ou "teatros" propriamente ditos foram inaugurados no Pará, Bahia, Rio de Janeiro, Minas Gerais, Pernambuco, São Paulo e Rio Grande do Sul (PRADO, 2012). No Rio de Janeiro, uma companhia artística estável dedicada à música, ao teatro e a ópera já funcionava regularmente nessa época, incluindo cantores, dançarinos e cômicos (CAVALCANTI, 2004). Um espaço para a promoção de uma sociabilidade pública também foi edificado no mesmo período: o Passeio Público do Rio de Janeiro, que integrava esforços para adequar a cidade aos conceitos iluministas de vida civilizada e educação requintada (DIAS, 2013). Em Minas Gerais, no mesmo sentido, o teatro e o mercado de músicas também já se mostravam bastante dinâmicos no período (BUDASZ, 2008).

Diante desse cenário, a partir de apontamentos históricos panorâmicos sobre o assunto, elaborados por meio de uma revisão ampla, ainda que não exaustiva, um primeiro propósito deste artigo é indicar que o desenvolvimento comercial do lazer, 
uma espécie de protoindustrialização da cultura, se deu antes do período que geralmente se aponta, isto é, antes da década de 1960. Uma cadeia produtiva da cultura socialmente dinâmica e em alguns aspectos até economicamente próspera existiu desde bem antes da década de 1960. Mais que isso, pelos legados e influências que exerceriam depois, seja na linguagem seja nos modos de organização da oferta comercial de lazer, esses "antecedentes" foram muito importantes para o desenvolvimento posterior desses setores. Reflexões sobre o lazer e a cultura no Brasil, no entanto, parece subestimar realizações anteriores a década de 1960, marcadas que estão por visões históricas de curto prazo. Uma reflexão sobre o assunto dentro de um arco temporal maior, talvez seja um passo importante para superar limitações desse tipo.

Além disso, pretende-se também esboçar aqui uma interpretação um pouco mais geral sobre o assunto, onde esse processo de mercantilização das diversões aparece como um dos aspectos mais importantes para a explicação da emergência histórica do lazer. Mais até do que a virtual separação entre trabalho e não trabalho, tão usualmente apontada como característica distintiva fundamental das formas modernas de ocupação do tempo livre, a subordinação das oportunidades de diversão a uma racionalidade econômica, orientado para a busca do lucro e consumida como forma de entretenimento por uma audiência ampliada através de pagamentos em dinheiro, foi uma das pedras de toque da singularidade histórica do lazer na modernidade. Nesse sentido, noções abstratas como "lazer mercadoria", surpreendentemente populares entre alguns estudiosos do lazer, são não apenas redundantes, como também inteiramente esvaziadas de significado histórico. Não houve um momento preciso em que o lazer se tornou uma mercadoria, simplesmente porque o lazer sempre foi uma mercadoria. 
Apesar dos indicativos positivos sobre o desenvolvimento econômico nos fins do século 18, o mercado consumidor interno do Brasil ainda parecia bastante restrito nessa época. Não por acaso, quase toda a oferta de espetáculos públicos capazes de servir ao divertimento da população era em grande medida organizada e financiada com recursos do governo. Com exceção de alguns setores específicos, como teatro, música ou a comercialização de bebidas e jogos em tabernas, quase não havia um mercado de consumo para diversões no período colonial (cf. ALGRANTI, 2011; BRESCIA, 2011; BUDASZ, 2008; MELO, 2016). Aparentemente, apenas ao longo do século 19, um universo de diversões crescentemente pulsante ganharia forma. Parte desta crescente efervescência no universo das diversões decorreu da progressiva subordinação das práticas lúdicas a mecanismos de comercialização. Transformações sociais e econômicas mais gerais explicam grandemente o processo.

A transferência da família real portuguesa para o Brasil, em 1808, como consequência das guerras napoleônicas na Europa, criou uma inédita demanda por consumo de bens e serviços, incluindo o consumo cultural ou a fruição de espetáculos públicos para o lazer. Embora existam controvérsias sobre o número de pessoas que viajaram na esquadra de navios que transportava a família real portuguesa de Lisboa para o Rio de Janeiro, é certo que se tratou de contingente considerável. As estimativas oscilam de 10 a 20 mil pessoas, muitas das quais, servidores bem pagos ou ricos portadores de títulos de nobreza; ambos os grupos com ambições culturais compatíveis com o gosto predominante nos maiores centros europeus. Tratava-se, em suma, de pessoas com características e em quantidade suficiente para promover autêntica revolução nos costumes de uma cidade e até de um país, como de fato aconteceria dali 
em diante. Não por acaso, Sergio Buarque de Holanda (1983) se referiu a este processo como o "novo descobrimento do Brasil" (p. 12).

Além das novas demandas por lazer, a expansão do mercado cultural que se seguiu à transferência da família real portuguesa para o Brasil expressaria também um claro desejo de distinção social por meio da exibição pública de status. Numa sociedade tão estratificada, a manutenção de hierarquias e vínculos de lealdade e subordinação dependia bastante da ostentação regular e sistemática de símbolos de riqueza e poder. Espetáculos cumpriam esse papel.

Até esse momento, apesar de já ser a cidade mais populosa da América Portuguesa, o Rio de Janeiro podia ainda ser visto como uma aldeia bisonha e sonolenta, com 19 praças e 46 ruas de terra batida, desniveladas, esburacadas, cheias de poças, detritos, brejos e mangues. A partir de 1810, contudo, deflagraram-se vários processos de desenvolvimento urbano, que acabaram por incluir esferas direta ou indiretamente relacionadas ao lazer de parte da sua população, como a criação de um horto botânico em 1811 (aberto ao público em 1819), uma biblioteca pública em 1814, um museu e uma escola de artes e ciências em 1816. Eram todas iniciativas do poder imperial.

Em 1813, o viajante inglês John Luccock (1942), que residiu no Brasil entre 1808 e 1818, quando se mostrara, em geral, bastante antipático aos costumes locais, registrou em seu diário o quanto as diversões, e o teatro, em particular, aprimoravam-se no Rio de Janeiro depois da chegada da família real portuguesa. Segundo ele, "as distrações do teatro progrediam de par com os assuntos de maior importância” (p. 163). 
$\mathrm{Na}$ verdade, medidas administrativas do governo influenciaram o mercado de diversões de várias formas. Além da criação de hortos, museus, bibliotecas ou escolas de artes, o poder imperial também aumentou a cunhagem de moedas de ouro, que foram quintuplicadas entre 1808 e 1818. A medida aumentava a oferta monetária, dando novo impulso a transações comerciais realizadas por meio do pagamento em dinheiro, ao invés do escambo ou outras formas mais arcaicas de comércio, como o pagamento com farinha de mandioca. Inovações desse tipo, porém, eram mais notáveis nos núcleos urbanos. Regiões rurais, que compunham a maior parte do contingente populacional do período, seguiam ainda bastante marcadas por uma economia de subsistência, com amplo emprego de mão de obra escrava. O Rio de Janeiro, de maneira excepcional, constituía-se, já nessa época, como um mercado consumidor relativamente grande, conforme avaliação de Celso Furtado (2007).

A partir dessa época, anúncios de jornais do Rio de Janeiro registravam crescente movimentação no mercado de música, com a oferta e venda de instrumentos, aulas, serviços de músicos ou convocações para espetáculos (MONTEIRO, 2008). O número de livrarias, no mesmo sentido, saltou de apenas 2, em 1808, para 16, em 1820; número que chegaria a 45 no final daquele século (HALLEWELL, 1985, p. 47). É pouco se comparado com outros centros urbanos, como Paris, que tinha 480 livrarias já em 1820, mas bastante se comparado com a situação local anterior. O número de jornais em circulação, crescente, do mesmo modo, chegaria a 60 por volta de 1850 (SODRÉ, 1999).

A população do Rio de Janeiro cresceu de pouco mais de 50 mil habitantes em 1808, para quase 120 mil em 1818 - um aumento de $140 \%$, em 10 anos, portanto. Em 1854, esse número ultrapassaria os 150 mil habitantes, numa época em que as 
populações das províncias de Minas Gerais, Bahia e Pernambuco ultrapassariam ou estariam próximas a 1 milhão de pessoas cada. Paralelamente, tomando o Brasil como um todo, houve também redução progressiva do percentual de escravos na população, que era de 30\% em 1808, 23\% em 1854 e 15\% em 1872 (BOTELHO, 2005).

O crescimento populacional, associado a progressiva redução do número de escravos, cuja mão de obra precisava ser substituída por trabalhadores livres e assalariados, pode ter afetado o mercado do lazer, pois uma maior disponibilidade de público consumidor com mais possibilidade de pagar em dinheiro por sua diversão pode criar mais oportunidades de investimentos e trocas comerciais no setor da oferta de serviços de entretenimento. A própria riqueza gerada pelo comércio internacional, além disso, também pode ter afetado a oferta comercial de diversão. Ricos proprietários de fazendas ligados ao comércio internacional de produtos agrícolas muitas vezes fixavam residência em centros urbanos, ou ao menos viajavam até ali regularmente, a fim de tratar de negócios ou buscar diversões. Esses hábitos se tornaram ainda mais frequentes com a expansão da rede ferroviária a partir do quartel final do século 19, que facilitou o trânsito entre o campo e a cidade. Como disse Emília Viotti da Costa (1999), “à medida que os fazendeiros se mudaram para os grandes centros, cresceu a tendência em promover melhoramentos urbanos. Aumentou o interesse pelas diversões públicas, a construção de hotéis, jardins e passeios públicos, teatros e cafés" (p. 256).

No Brasil de meados do século 19, a proibição do tráfico de escravos (1850) induziu a um refluxo de investimentos nesse setor, até então bastante rentável, liberando capitais que seriam canalizados para outras iniciativas, entre as quais, o mercado 
financeiro, o comércio e os serviços urbanos. Além disso, a crescente demanda por escravos nas novas fazendas de café de São Paulo, necessários para atender uma produção também crescente, de acordo com as necessidades do mercado internacional, incentivou a transferência de escravos da cidade para o campo, cujas ocupações urbanas foram então progressivamente substituídas por trabalhadores livres. Por volta de 1870, em cidades como o Rio de Janeiro, onde a concentração de escravos era grande, acima da média nacional, observadores contemporâneos já podiam notar nessa época uma presença maior e socialmente significativa do trabalho livre (COSTA, 1997). A estagnação da produção de café nas velhas fazendas do Rio de Janeiro (da região do Vale do Paraíba) também incentivou os fazendeiros a se envolverem economicamente em outros setores. Quando os preços do café caíram repentinamente na década de 1880, ficou ainda mais claro para os grandes fazendeiros as vantagens de se diversificar os investimentos.

Todas essas mudanças, em suma, parecem ter afetado em alguma medida o mercado das diversões, que tinha já seus empresários especializados, com uma oferta cada vez mais diversificada de atrações, incluindo, principalmente, espetáculos de circo e teatro. A oferta comercial do lazer a partir dos meados do século 19 parece ter aumentado, contando não apenas com capitais antes destinados ao tráfico de escravos, mas provavelmente também com os lucros gerados pela produção de café para o mercado internacional. Por volta da década de 1840, o café já representava o principal produto de exportação da economia brasileira, superando o açúcar e o algodão, respondendo, então, por mais de $40 \%$ do valor das exportações do país. 
Já na década de 1830, a atividade teatral do Rio de Janeiro instigava iniciativas empresariais no setor, refletindo e ao mesmo tempo estimulando o interesse de um público diversificado. É dessa época a fundação de teatros ou companhias teatrais e também do aumento de registros de desordens em espetáculos da cidade, evidenciando a ampliação dos interesses e dos perfis do público. Entre 1824 e 1843, ao menos dois regulamentos policiais legislavam sobre o modo de funcionamento de teatros no Rio de Janeiro, o que reforça a crescente preocupação governamental com um costume que se disseminava, ao mesmo tempo em que revela a multiplicidade de sentidos atribuídos a espetáculos teatrais. A presença da polícia nos teatros, afinal, contrariava os ideais de civilidade e elegância que grupos de elite se esforçavam em consolidar ao redor desses espaços. O escritor e político Joaquim Manoel de Macedo, chegou a afirmar, em artigo no Jornal do Commercio, que o teatro não podia, nem devia ser simplesmente um passatempo, em afirmação que seria repetida às vezes literalmente por outras pessoas em várias partes do país (SOUZA, 2002, p. 269).

Na prática, no entanto, além dos propósitos educativos e civilizadores que elites letradas reivindicavam para os teatros, costumes da população que os frequentavam remetiam também às possibilidades de diversão, o que foi abertamente condenado por setores que desejavam the imprimir outros significados. Como Macedo, vários intelectuais criticaram abertamente ao longo de quase todo o século 19 a dimensão recreativa que ia se cristalizando no consumo de espetáculos teatrais. Na visão desses grupos, mais que meramente diversão, o teatro deveria ser encarado como assunto sério, capaz de fornecer educação e civilidade, influenciando positivamente a mentalidade e o comportamento do povo, concebido como vulgar e ignorante; incapaz, portanto, de 
julgar e discernir por si só, o que obviamente justificativa as tentativas de grupos de elite em tentar controlar o modo como se organizavam e se assistiam espetáculos teatrais, bem como outras atividades de lazer. Por outro lado, as próprias elites letradas concebiam a si mesmas como portadoras de capacidades superiores, o que, até por isso, lhes responsabilizava na condução das massas incultas nesse processo em direção ao que se considerava sábio, civilizado e de gosto refinado.

Assim, os critérios que presidiam a oferta e a percepção que se tinha de espetáculos públicos distinguiam-se muito claramente, dependendo apenas da posição social que se ocupava. Para intelectuais, críticos e escritores, deveria distinguir-se dois diferentes gêneros de espetáculos. De um lado, àqueles destinados ao mero divertimento; de outro, àqueles destinados à educação e elevação espiritual do povo. Espetáculos com propósitos educativos, tidos como melhores, deveriam se organizar de modo a desprezar o mais possível as vontades e interesses do público, tidos, afinal, como incapazes e ignorantes. Já os espetáculos com finalidades de diversão, cuja existência poderia ser mais ou menos tolerada, a depender apenas da severidade do crítico que lhe julgava, poderiam, no mais das vezes, ser simplesmente ignorados. Espetáculos que deveriam ter conotações educativas, sobretudo no teatro, mas que apresentassem elementos tidos como característicos do universo das diversões populares, eram ainda mais duramente criticados. Tais ocasiões, além de borrar as fronteiras entre diferentes gêneros de espetáculos, acabavam por subordinar o seu desejado caráter educativo e civilizatório a dimensões mais lúdicas e comerciais, orientada para o prazer e a diversão. De acordo com as concepções que predominavam, nada seria mais inadequado. 
De modo totalmente diferente, para os empresários que lideravam iniciativas nesse setor, interessados em obter lucro e sustentar comercialmente seus negócios, atender as expectativas do público era não apenas uma opção, mas uma necessidade, quase independentemente do gênero de espetáculos a que se dedicavam (dramas, revistas, mágicas, operetas, burletas, ginásticas ou touradas). Nesses termos, empresários poderiam até compartilhar das concepções de outros grupos da elite a respeito do povo, vendo-os como incapazes e ignorantes. O que não podiam é desprezar os interesses populares a respeito do que deveria ser apresentado em espetáculos, uma vez que dependiam inteiramente do dinheiro do povo que comprava ingressos para assisti-los.

$\mathrm{Na}$ ausência do mecenato governamental, que no século 19 apenas ocasionalmente oferecia subsídios, era a expectativa do público disposto a pagar por ingressos o que determinava o que deveria ser ofertado nos palcos, picadeiros ou arenas de touros. Por meio do dinheiro, o público, visto por intelectuais como culturalmente despreparado, podia, na prática, exercer influência sobre os empresários. Em certos casos, grupos ocupacionais específicos, como os dos trabalhadores do comércio, chegaram mesmo a publicar anúncios em jornais pedindo a apresentação ou reapresentação de peças teatrais da sua preferência, prometendo, em contrapartida, lotar os teatros, caso tivessem seus desejos atendidos (SOUZA, 2002). Situações análogas de negociação entre público e organizadores aconteciam também em outros gêneros de divertimento, como as touradas (MELO, 2017).

Do ponto de vista dos empresários e também do público, sequer a distinção entre espetáculos com propósitos de diversão ou de educação parecia fazer sentido. Teatro, circo e touradas muitas vezes compunham simultaneamente a linguagem dos 
espetáculos em meados do século 19. Havia uma justaposição de diferentes práticas. Touradas combinavam-se com atividades equestres ou exibições de ginástica. Teatros poderiam também ser entremeados por apresentações musicais ou de ginástica. Não por acaso, atores de teatro poderiam encontrar fértil espaço não só de atuação, mas também de formação artística em apresentações populares em feiras ou festas religiosas (ABREU, 1999). Ingressos para alguns desses espetáculos poderiam ser vendidos em livrarias. Espetáculos de óperas, no mesmo sentido, também se relacionavam com o nascente mercado editorial. Segundo cálculos de Laurecen Hallewell, em meados do século 19 , aproximadamente $75 \%$ das edições de uma livraria do Rio de Janeiro eram libretos de ópera (HALLEWELL, 1985, p. 88). E apesar de todo o esforço retórico que havia no período para separar arte e diversão, lazer e cultura, esses universos permaneceriam indissociáveis até anos avançados do século 20.

Ainda por volta das décadas de 1920 ou 1930, quando uma segmentação mais precisa dos diversos setores dos mercados do entretenimento já se fazia notar, diferentes gêneros de diversão comercial operavam ainda de maneira articulada. Parque de diversões, choperias, confeitarias, cafés-concerto, restaurantes ou casas dedicadas aos jogos de azar ofereciam comidas, bebidas, lutas, jogos e exibições de filmes, além de espetáculos de teatro, música, ginástica ou mágica. Do circuito das “casas de tavolagem" e de bancas do "jogo do bicho", onde se promoviam legal ou ilegalmente diversos jogos de azar, sairiam alguns dos mais importantes empresários do setor do entretenimento urbano das primeiras décadas do século 20, sobretudo nos ramos do cinema e do teatro popular. Foi este o caso de Francisco Serrador e Paschoal Segreto, imigrantes espanhol e italiano, respectivamente, que alcançaram riqueza e até notoriedade com suas empresas de cinemas, teatros e outras diversões (MORAES, 
2014a). Do mesmo modo, músicas que fariam grande sucesso no carnaval, no rádio ou na venda de discos, foram antes elaboradas especialmente para espetáculos teatrais. Em meados do século 20, casinos e boates também eram espaços de atuação importantes, tanto para artistas do teatro quanto da música.

\section{5}

Nesses termos, que embaralham classificações, o circo, ao lado do teatro, foi outra importante instância na oferta de serviços culturais destinados ao lazer no século 19. Já em 1818 ou 1819 há notícias da presença no Rio de Janeiro de um circo de um artista inglês, vindo de Buenos Aires: a Companhia Inglesa de Cavalinhos, de Guillermo Southby, cujos espetáculos seriam registrados nos anos seguintes em cidades de outras regiões do país (SILVA, 2007). A partir de 1830, aproximadamente, o circo era um dos espetáculos públicos mais regularmente organizados, não apenas no Rio de Janeiro, se não também em outras partes do país. Em Minas Gerais, várias cidades conheceram ao longo daquele século uma intensa movimentação de espetáculos de teatro e circo (DUARTE, 1993).

A maneira como os espetáculos de circo estavam estruturados nessa época, da mesma forma que outros gêneros de entretenimento, tornavam-nos profundamente articulados com outras atividades de lazer, como os próprios teatros ou as festas religiosas, que constantemente incorporavam palhaços, mágicos, ginastas, trapezistas, dançarinos, cantores ou outras formas de exibição vistas depois como tipicamente circenses. Tudo isso tornava difícil, se não impossível, marcar uma fronteira rígida entre esses diferentes gêneros de diversão. 
De modo semelhante, também as touradas, antes limitadas apenas a iniciativas governamentais, a partir da década de 1840, aproximadamente, tornaram-se mais empresariais, isto é, organizadas por iniciativas de empresários que visavam explicitamente o lucro. No final daquela década, duas novas arenas de touros chegaram a funcionar simultaneamente no Rio de Janeiro, cada uma delas administrada por diferentes empresários. Os dois responsáveis pelos empreendimentos chegaram a desenvolver aberta rivalidade entre si. Registros de touradas já dentro desse modelo de organização empresarial também são localizados na Bahia e em São Paulo a partir de 1870 (MELO, 2017).

\section{6}

Entre as décadas de 1840 e 1850, inicia-se um movimento social cada vez mais intensivo de exploração comercial de diversões e espetáculos públicos. Nessa época, um excesso de ofertas de diversões já poderia inclusive ser apontado, como o fizera um cronista anônimo do jornal Correio da Tarde, do Rio de Janeiro. Segundo palavras dele, "temos dois teatros na Corte; duas praças de touros; de vez em quando bailes mascarados que se consentem em todo o decurso do ano, dando-se carro de graça às madamas para a ida; além disso, temos Sociedades de Bailes, A Filarmônica etc. etc. Isto estafa" (MELO, 2017).

Nessa época, companhias dramáticas claramente motivadas com o propósito de explorar comercialmente a oferta de espetáculos teatrais são inauguradas no Rio de Janeiro, chegando a alimentar rivalidade entre si. Cambistas já atuavam comprando ingressos a fim de revendê-los por preços mais caros depois, tentando também obter vantagens financeiras com a intensificação do consumo de espetáculos teatrais. Figuras 
como João Heliodoro, proprietário de uma companhia dramática, frequentemente era representado na imprensa da época como um "capitalista", isto é, conforme palavras de um cronista anônimo do jornal Correio Mercantil, "um homem que só tomou a direção do teatro impelido por vistas ambiciosas e cálculos mercantis" (SOUZA, 2002, p. 100).

De fato, anúncios publicitários da companhia dramática de João Heliodoro, publicados em jornais do Rio de Janeiro, destacavam que os preços dos bilhetes praticados ali eram menores que os cobrados por outros teatros, explicitando a preocupação econômica do empresário em atrair o público por meio da redução desses valores. Em 1855, confirmando a tendência geral de mercantilização no universo das diversões da época, comentários sobre exibições teatrais publicados na imprensa do Rio de Janeiro poderiam destacar já uma "lucrativa afluência de espectadores" (SOUZA, 2002, p. 59).

Alheios a propaganda educativa e civilizadora que elites letradas tentavam impor aos espetáculos teatrais, o público mostrava-se especialmente interessado em novidades capazes de lhes excitar e causar emoção, o que os empresários envolvidos nesse ramo de atividades tentavam prontamente atender, visando, claro, explorar o mais possível as oportunidades comerciais geradas por esta demanda. Conforme registrara em 1855 o jornal A Marmota, do Rio de Janeiro, "raro é o domingo que os cartazes [de espetáculos de teatro] não convidam o público para ser testemunha de alguma novidade" (SOUZA, 2002, p. 64). De fato, nessa época, uma única companhia de teatro poderia estrear 25 diferentes comédias em apenas 6 meses, o que equivalia a oferta de um novo espetáculo a cada semana. Touradas e espetáculos de circo também se empenhavam em incorporar 
inovações, inteiramente em conformidade a essas expectativas por novidades excitantes, que iam caracterizando as predileções do público da época.

Na segunda metade do século 19, quando se consolida o mercado das touradas, uma das principais preocupações de empresários ligados a este setor estava em garantir animais suficientemente ferozes para os espetáculos, indo claramente ao encontro das expectativas do público. Empresários chegaram a buscar touros em outros países (ou ao menos a dizer que o faziam), sob a promessa de se tratarem de animais de raça superior e em mais condições, portanto, de oferecer dificuldades ao toureiro, tornando a exibição mais atraente, justamente porque mais emocionante, o que era devidamente enfatizado nas propagandas que antecediam tais espetáculos. Quando os animais não se mostravam tão ferozes quanto prometiam as propagandas, o público prontamente manifestava seu descontentamento, criticando o evento em cartas publicadas nos jornais, vaiando a performance dos toureiros durante suas exibições ou mesmo quebrando as arenas onde se realizavam as touradas. A busca por novidades e emoções era um fator tão importante na estruturação das touradas no século 19, que a ausência desses elementos poderia significar o fracasso comercial do negócio, como aconteceu em alguns empreendimentos, cujos animais tinham pouca ferocidade (MELO, 2017).

Embora a historiografia da cultura destaque a transição entre os séculos 19 e 20 como principal época para as transformações dos lazeres em direção ao gosto por novidades e emoções fortes, no que Ben Singer (2004) chamou de "sensacionalização do divertimento comercial", algo semelhante, se bem que mais difuso e em escala menos intensa, já se processava desde meados do século 19. Ainda não se tratava de lazeres cujas percepções sensoriais estivessem marcadas de maneira socialmente generalizada pela fragmentação e velocidade, como seria no século 20, mas 
características nesse sentido já se faziam notar de modo às vezes bastante agudo. Mesmo em circunstâncias sociais mais periféricas, como a brasileira, onde a intensidade da vida urbana e o poder aquisitivo de grande parte da população eram ainda limitados, transformações na esfera do lazer já mostravam alguns desses traços. Em meados de 1808, registros de John Luccock (1942) a respeito de uma peça teatral encenada no Rio de Janeiro, deixava notar o tipo de espetáculo que parecia atrair o interesse do público já naquela ocasião. Segundo ele:

Muitas das peças dramáticas contêm cenas que uma pequeníssima dose de bom-senso e bom-gosto haveria de banir para sempre do palco [...] A heroína, trajada de musselina branca, devia ser morta, enquanto o pano estava abaixado, separando-se lhe a cabeça do corpo. Isso, penso eu, deveria constituir o fim do seu papel, em qualquer teatro que não fosse brasileiro; pois bem, logo a seguir, levanta-se de novo o pano sem outro fim que o de exibir ao público o corpo decapitado da dama, sentado direto numa poltrona, com o sangue borbulhando de seu pescoço e correndo pelo seu vestido abaixo (p. 60).

Anos depois, em 1858, um cronista anônimo do jornal Correio Mercantil, do Rio de Janeiro, registrou a consagração definitiva do tipo de espetáculos que marcava a predileção do público na época. Segundo ele, "o povo só gosta de divertimento quando vê perigo, e quando mesmo vê sangue" (MELO, 2017). Os próprios gêneros de divertimento que compunham a oferta de lazer da época, ampliavam-se com novas modalidades, igualmente compatíveis com essa estrutura de sentimentos, orientadas pelo prazer com a novidade e a excitação, como era o caso das corridas de cavalo, cujo primeiro espaço no Brasil fora inaugurado em 1851, no Rio de Janeiro (MELO, 2001). Até o fim daquele século, considerando apenas o que já sabemos com certeza, de maneira bem documentada, iniciativas para construção de locais para corridas de cavalo e eventualmente outros esportes voltados para a intensificação de emoções e celebração da velocidade, como as corridas de bicicleta, teriam lugar no Rio de Janeiro, São Paulo, 
Manaus, Belém, Maceió, Curitiba, Porto Alegre e Recife, além de mais de uma cidade de Minas Gerais.

Ainda no século 19, surgiriam também novos gêneros de espetáculos cênicos, que diversificaram o tipo e aumentaram a quantidade da oferta cultural. Era este o caso do "teatro de variedades" ou dos "cafés-cantantes", que combinavam apresentações de mágicas, imitações, ginástica, operetas, fantoches, músicas e danças, geralmente acompanhadas pelo consumo de bebidas alcoólicas. Em todos os casos, tratavam-se de casas de espetáculos marcadamente populares, vistas, em várias ocasiões, como bons negócios comerciais (TINHORÃO, 1998).

Todo esse contexto, em suma, evidencia três importantes transformações que se processaram no universo do lazer ao longo do século 19, e que ganhariam contornos cada vez mais claros no século seguinte: 1) a tendência em se fortalecer fronteiras para separar lazer e arte, cultura e entretenimento, criando modalidades cada vez mais separadas e especializadas; 2) a predileção do público por diversões que representassem novidades, ao mesmo tempo em que gerassem emoções fortes; 3) a subordinação da organização e oferta de atividades de lazer aos mecanismos de uma economia de mercado.

Ao lado das novidades e das emoções excitantes, era o dinheiro, portanto, o novo critério fundamental a presidir a organização de inúmeras atividades de lazer. Segundo opiniões vinculadas em mais de uma ocasião em jornais da época, pessoas envolvidas com a organização de espetáculos e diversões com caráter claramente comercial estariam mesmo afetadas por uma "febre de fortuna" (SOUZA, 2002, p. 236). Em 1896, o escritor Machado de Assis (2008), sempre atento as transformações que se processavam na sociedade de sua época, registraria ironicamente, como era de seu 
costume, o crescente domínio do dinheiro em várias esferas do período, em crônica do dia 2 de agosto, do jornal Gazeta de Notícias:

Mete dinheiro na bolsa - ou no bolso, diremos hoje, e anda, vai para diante, firme, confiança na alma, ainda que tenhas feito algum negócio escuro. Não há escuridão quando há fósforos. Mete dinheiro no bolso. Vende-te bem, não compres mal os outros, corrompe e sê corrompido, mas não te esqueças do dinheiro, que é com que se compram os melões. Mete dinheiro no bolso (p. 1.304).

Por volta de 1870, a expansão mundial da indústria, envolvendo cada vez mais outros países que não apenas a Inglaterra, intensificou a concorrência e ampliou as oportunidades comerciais de países produtores de matérias-primas. Foi claramente este o caso do Brasil. A participação do Brasil na grande expansão do comércio e das finanças mundiais como fornecedor de matéria-prima depois de 1870 deflagrou novo tipo de desenvolvimento econômico no país, desencadeando forças produtivas e sociais inéditas.

Entre 1870 e 1920, a população do país cresceu de 10 milhões de pessoas, para aproximadamente 30 milhões. O percentual de pessoas que viviam em áreas urbanas com mais de 20 mil habitantes saiu de 8 para 13\% no mesmo período; proporção que seguiria crescendo em ritmo cada vez mais acelerado nas décadas seguintes. Em larga medida, esse crescimento populacional, especialmente nos setores urbanos, esteve relacionado com o comércio de exportação, que exigia maior mão de obra, ao mesmo tempo em que impulsionava vários setores da economia. Não por acaso, as cidades cujas populações mais cresceram nesse período foram àquelas mais diretamente envolvidas nesse ramo de negócios, como era o caso do Rio de Janeiro e São Paulo, que concentravam mais da metade da população urbana em 1920. Na verdade, o setor de exportação proporcionou tanto a demanda quanto o capital para a expansão de um 
mercado de consumo interno. Sintomaticamente, muitas das primeiras fábricas criadas no Brasil eram de produtos ligados à produção agrícola, como tecido para ensacar café, que era o principal produto agrícola de exportação, além de serem de propriedade de fazendeiros que exportavam suas produções (especialmente de café ou algodão) (DEAN, 2008). Do mesmo modo, no setor do entretenimento urbano, alguns dos investidores que disponibilizavam capitais para a abertura de empresas de teatro, cinema e outros espetáculos de variedade, eram direta ou indiretamente ligados ao setor agroexportador (MORAES, 2014b).

\section{9}

As transformações estruturais que afetavam o Brasil desde o fim do século 19 estimularam a expansão de um mercado de consumo interno, mas que era ainda bastante incipiente. A própria oferta de entretenimentos, que em muitos aspectos crescia e se intensificava, continuava, porém, irregular, quando não esporádica. Era comum que modalidades ou locais de diversão surgissem repentinamente, antes de desaparecerem com igual rapidez. A efemeridade desses modismos pode estar relacionada com o próprio gosto do público por novidades que marcava o período, mas também com flutuações da economia, que aumentava ou diminuía disponibilidades financeiras frequentemente. Não por acaso, apesar de uma dinâmica de surgimento e desaparecimento repentinos de entusiasmos por certas diversões ter se mantido até anos avançados do século 20, uma diferença fundamental parece ter se inscrito na cultura do lazer depois de 1910 ou 1920, aproximadamente, dependendo da região. Desse período em diante, com o advento de uma sociedade de consumo verdadeiramente de massas, a oferta de diversões comercializadas seria ininterrupta, imprimindo perenidade e maior 
alcance social aos mecanismos de comercialização do lazer. Jornais, cinemas e pouco depois o rádio, sem mencionar os mais tradicionais bares, restaurantes ou salões de bilhares, ofereceriam oportunidades diárias ou quase diárias para o lazer e o consumo cultural de um amplo conjunto da população.

Limitações no mercado de consumo interno tenderam a ser tornar progressivamente menos flagrantes depois de 1888, quando a escravidão foi finalmente proibida. A escravidão, além da sua imoralidade, limitava as possibilidades de crescimento econômico, uma vez que o trabalho realizado por escravos geralmente não era remunerado em dinheiro, embora fosse este o caso em algumas ocasiões. Assim, o mercado de consumo restringia-se basicamente aos artesãos, lojistas e pequenos proprietários rurais que vendiam seus produtos agrícolas para o mercado das cidades, além de imigrantes europeus que chegavam em quantidades cada vez maiores a partir de 1890.

Trabalhadores livres pobres, porém, viviam geralmente em condições tão precárias que não tinham muitas possibilidades de integrar um mercado consumidor, exceto na aquisição de bens que fossem estritamente essenciais. As fronteiras entre o trabalho livre e o trabalho escravo permaneceram tênues por muito tempo ainda. Se havia escravos que ocasionalmente trabalharam por salário ou outras formas de remuneração em dinheiro, houve também, por outro lado, trabalhadores livres que trabalharam em troca de moradia, alimentação e proteção, com pouco ou nenhum pagamento em dinheiro, como se escravos fossem. A situação era bastante comum nas áreas rurais, mas também ocorria em áreas urbanas, onde diversas categorias de artesãos e funcionários do comércio frequentemente moravam no mesmo local de trabalho, que coincidia também com a residência do empregador, estreitando os vínculos de vigilância 
e dependência. Além disso, para os que recebiam salários em dinheiro, crises econômicas dificultavam o acesso ao mercado de bens e serviços. Entre 1890 e 1900 houve retratação de $20 \%$ dos ganhos econômicos gerais e da renda média per capita (FRANCO; LAGO, 2012, p. 199). Entre 1914 e 1916, o custo de vida teria aumentado 16\% (PINHEIRO, 2006, p. 157). Entre as décadas de 1920 e 1930, os salários oferecidos pelo mercado de trabalho mantiveram-se mais ou menos estáveis, enquanto o custo geral de vida registrou aumento. Por volta de 1932, segundo estimativas de Decca (1987), um trabalhador pobre de São Paulo gastava 50\% de sua renda com alimentação, $25 \%$ com habitação, $15 \%$ com vestuário e $10 \%$ com outras compras diversas. Nesse contexto, a compra de ingressos para cinemas populares poderia consumir $1 \%$ ou mais do salário mensal usualmente pago a um operário. Apesar de todas essas limitações, todavia, havia já um mercado consumidor interno relativamente grande, onde o setor de serviços equivalia a 50\% ou mais de toda economia nacional (LEOPOLDI, 2003).

Um mercado de consumo interno maior, mais sólido e mais geograficamente generalizado começou a se incrementar a partir da primeira ou segunda década do século 20, com a expansão de uma "classe média urbana", composta por militares, pequenos proprietários, profissionais liberais e funcionários públicos. Essas ocupações, todavia, ainda se restringiam quase inteiramente a alguns poucos centros urbanos, ficando todo o resto da população do país empregada em setores de produção agropecuária. Em 1920, quase 70\% da população ativa estava empregada em atividades do setor agrícola, onde predominavam métodos de remuneração mais primitivos, às vezes sem nenhuma presença de pagamento em dinheiro. Com efeito, em áreas rurais, que concentraram o maior contingente populacional no Brasil até os idos das décadas de 1960, quando finalmente o número de pessoas vivendo em áreas urbanas superou as que 
viviam em zonas rurais, era comum que camponeses oferecessem seus serviços em troca de proteção, de pequenos favores ou pelo direito de plantar alimentos para subsistência em trechos das fazendas cedidos pelos proprietários.

Apesar de todas essas limitações estruturais, o mercado de comercialização de lazeres em massa floresceu progressivamente a partir de princípios do século 20, o que não deixa de ser surpreendente diante das condições gerais que marcavam a vida social do Brasil na época. Em 1908, um cronista do jornal Gazeta de Notícias, do Rio de Janeiro, sintetizou algumas das percepções de muitos de seus contemporâneos diante das transformações no universo das diversões públicas do período. Segundo palavras dele:

Anteontem, sábado, tivemos durante o dia o disputadíssimo match de futebol. À noite funcionou o Lírico, o São Pedro, o Recreio, o Carlos Gomes, o Apolo e o Palace-Theatre [nomes de teatro da cidade]. Havia ainda os cinematógrafos. Pois bem. Todas essas casas de diversões estiveram repletíssimas. Ontem, domingo, quer durante o dia, quer durante a noite, todos os lugares estiveram cheíssimos. E ainda houve corridas. Já não falamos nas missas, nas recepções, nas soirées, nas récitas dramáticas particulares, nas festas dos clubes, nos bailes, em mil e outra diversões e passeios. O Rio diverte-se (SOUZA, 2003, p. 131).

Desde princípios do século 20 , de fato, a quantidade e a diversidade de atividades de lazer são crescentes em várias cidades do Brasil. O processo claramente extravasou o eixo Rio-São Paulo, embora ali o fenômeno tenha assumido dimensões especialmente intensas. Em 1922, dados oficiais do governo contabilizaram 1.439 teatros e outras casas de espetáculos espalhadas por todo o Brasil, embora de maneira desigual. Todos os 287 teatros e casas de espetáculos do atual nordeste brasileiro, que concentrava $36 \%$ da população brasileira na época, representavam pouco menos de $20 \%$ do total dessas instalações, somando menos que àqueles disponíveis separadamente nos 
Estados de São Paulo e de Minas Gerais, que eram os locais que reuniam a maior quantidade: 398 e 312 , respectivamente (INSTITUTO NACIONAL DE ESTATÍSTICA, 1936, p. 367). Por outro lado, surpreendentemente, a quantidade média de teatros e casas de espetáculos disponíveis para cada habitante do Mato Grosso, Paraná e Acre, era equivalente ou até superior aos índices de Minas Gerais, Rio de Janeiro e São Paulo, o que além de eventuais condições estruturais favoráveis ao desenvolvimento comercial de um mercado de diversões nessas regiões, revela também o esforço das elites locais em aderir a certo imaginário de modernidade. Todavia, o adensamento urbano das capitais do Rio de Janeiro e de São Paulo, que em 1920 somavam mais de 1 milhão e meio milhão de habitantes, respectivamente, contrastando com a típica dispersão populacional que caracterizava o padrão de ocupação territorial de outras regiões, tendia a acentuar em muitos homens e mulheres da época a percepção de que a vida nessas duas metrópoles brasileiras era mais intensa, dinâmica e moderna, como de fato era.

Gráfico 1. Teatros e casas de espetáculos no Brasil por habitante (1922)

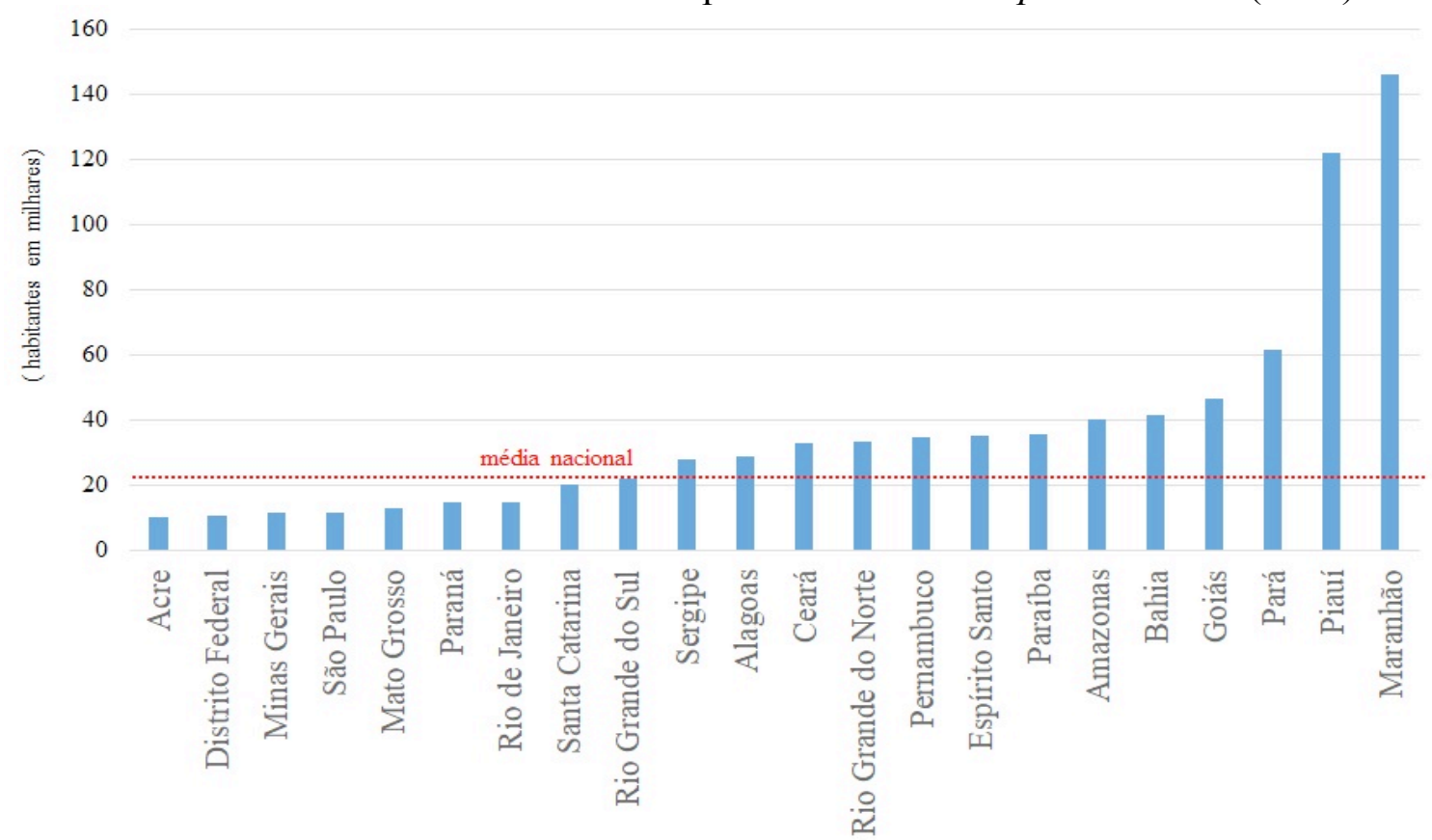


Fonte: Instituto Nacional de Estatística, Anuário Estatístico do Brasil. Ano II, Rio de Janeiro, Typographia do Departamento de Estatística e Publicidade, 1936, p. 367. Elaboração do autor.

Somente nas cidades do Rio de Janeiro e de São Paulo, havia dezenas de teatros até o fim da primeira década do século 20, com apresentações às vezes diárias. O número de filmes lançados nos cinemas dessas duas cidades também aumentou no período, saltando de pouco mais de 850, em 1907, para quase 2.000, em 1909 (SOUZA, 2003, p. 176). Concorreu para este desenvolvimento o início da produção e distribuição de filmes em larga escala por empresas europeias, principalmente francesas, italianas, alemãs, suecas e dinamarquesas, que eram as fornecedoras mais importantes do mercado brasileiro até a Primeira Guerra Mundial, quando foram paulatinamente substituídas por empresas norte-americanas. A ampliação da rede de fornecimento de eletricidade é outro fator associado ao crescimento dos cinemas em princípios do século 20, uma vez que facilitou a exibição de filmes de maneira regular e em estabelecimentos fixos, no lugar de exibições ocasionais e itinerantes. A relativa prosperidade do mercado de trabalho entre 1905 e 1913, relacionada com um surto industrial e com êxodo rural em consequência de uma crise no setor de produção e comercialização internacional do café entre 1898 e 1907, pode também ter desempenhado algum papel nesse processo.

Na transição entre as décadas de 1910 e 1920, o Rio de Janeiro contaria, no mínimo, 76 salas de cinema, 12 teatros e 35 circos, além de inúmeros bares, restaurantes, confeitarias e outros estabelecimentos que também promoviam espetáculos com o propósito de divertir, em estimativas que provavelmente são subestimadas (GOMES, 2004, p. 34). Em São Paulo, no mesmo sentido, o número de salas de cinema saiu de 47, em 1911, para mais de 70, em 1919. Até o número de exibições diárias nos cinemas dessas cidades aumentou no período. Nessa época, observadores como o escritor Olavo Bilac falavam já de uma "mania cinematográfica", que invadia não 
apenas os cinemas das cidades, como também os teatros e praticamente qualquer outro espaço improvisado como local de exibição. "Daqui a pouco", dizia o escritor, referindo-se ao Rio de Janeiro, "não poderemos dar um passo pela cidade, sem encontrar diante dos olhos um desses lençóis alvos em que as cenas da vida humana apareçam deformadas pelo tremor convulsivo da fita" (BERNARDET, 1995, p. 75).

Com proporções talvez menos impressionantes, mas nem por isso menos relevantes, a mesma dinâmica cultural seria registrada em várias regiões do país, fossem capitais, fossem cidades do interior. Em Recife, por exemplo, mais de 50 cinemas seriam abertos entre 1909 e o fim dos anos 1910. Eram instalações de tamanho e sofisticação variados, muitos dos quais tiveram vida curta. De todo modo, apenas entre 1924 e 1926, desconsiderando pequenas casas de projeção espalhadas por vários bairros, a cidade contava mais de 20 cinemas, muitos dos quais funcionavam também como teatros e espaços para espetáculos de variedades (COUCEIRO, 2003). Em Belo Horizonte, rigorosamente no mesmo sentido, sessão de um jornal local especialmente dedicada a noticiar as diversões da cidade, registrou a substituição do teatro, das apresentações musicais e das festas sociais, formas de entretenimentos dominantes nos anos finais do século 19, em favor dos esportes e da "febre dos cinematógrafos" (SOUZA NETO; SILVA, 2009). De fato, a partir de 1906, após exibições esporádicas ou itinerantes realizadas antes, vários cinemas fixos foram instalados em Belo Horizonte (GOMES, 1997).

Outros segmentos do mercado de comercialização de diversões também experimentavam notável crescimento no período. Jornais diários e revistas semanais se organizavam cada vez mais claramente de modo empresarial, isto é, com divisão do trabalho nas redações, propagandas coloridas e a assimilação de outros avanços 
tecnológicos na impressão. Por volta de 1920, quando a propaganda se torna uma fonte importante de receita para alguns veículos de comunicação, para além das assinaturas e da compra de exemplares avulso, revistas como A Cigarra, A Vida Moderna e $O$ Pirralho, editadas não apenas para informar, mas sobretudo para entreter seus leitores e leitoras, contavam já tiragens entre 15 e 30 mil exemplares (PADILHA, 2001). No mercado musical, no mesmo sentido, a produção e comercialização de discos quase triplicou no final da década de 1920. Até 1932, 4 novas empresas estrangeiras e 3 nacionais se instalaram no Brasil para produção e comercialização de discos (GONÇALVES, 2013, p. 75-80).

Os esportes também seriam cada vez mais ofertados como possibilidades de diversão e consumo de espetáculos públicos em várias regiões do Brasil nesse período. De início, turfe, remo e ciclismo seriam as modalidades mais frequentes. Logo, natação, boxe, patinação, tênis, basquete, automobilismo, corridas a pé e, acima de tudo, o futebol, começariam a compor o universo de esportes praticados e assistidos - às vezes intermedidos por mecanismos de comercialização, muitas vezes não (para uma síntese de várias regiões, ver MELO, 2010). Até a década de 1930, se não antes, praticamente toda cidade brasileira, grande ou pequena, contaria ao menos uma equipe de futebol. Em 1937, dados oficiais registravam 849 campos esportivos espalhados por todo o país, excluindo "pequenos campos de 'foot-ball' e outros jogos sem aparelhamento próprio" (DIAS, 2018, p. 25). Entre 1941 e 1944, em outra expressão do crescimento desse setor, o número de ingressos para partidas de futebol vendidos no Rio de Janeiro aumentou 42\% no período, de 550 mil ingressos em 1941, para 783 mil em 1944 (PREFEITURA DO DISTRITO FEDERAL, 1946, p. 97). 
A crescente importância desta e de outras formas de lazer pode ser notada observando-se o espaço dedicado às suas divulgações nos jornais dos fins do século 19 e princípios do século 20 , bem como no surgimento de periódicos especializados no mesmo período: O Sportman (1887), A Vida Sportiva (1889), São Paulo Sportivo (1896), Estação Sportiva (1911), Sports (1915), Correio Sportivo (1916), Sport Ilustrado (1920), entre muitos, muitos outros.

Em alguns casos, iniciativas empresariais do setor de entretenimento estabeleceram amplas conexões internacionais. Mencionamos já que desde os meados do século 19, empresários que organizavam touradas importavam ou diziam importar touros e toureiros de outros países. No mercado editorial, algumas casas de mais sucesso imprimiam seus livros em gráficas da França ou de Portugal. Na música, a crise econômica dos fins da década de 1920, associada a uma crescente concorrência com o rádio, acabaram por diminuir o volume de vendas de empresas europeias e norteamericanas de fabricação de discos, como a Columbia ou a Odeon, animando a busca por novos mercados, entre os quais incluía-se o Brasil - primeiro país sul-americano a possuir uma fábrica de discos (GONÇALVES, 2013). No cinema, a Primeira Guerra Mundial quase interrompeu por completo o fluxo comercial entre exibidores brasileiros e produtores europeus, que era já bastante significativo nessa ocasião. Com isso, empresas norte-americanas iniciaram o processo de dominação do mercado brasileiro de exibição de filmes depois de 1914 (SOUZA, 2003).

No teatro ou na ópera, do mesmo modo, temporadas de companhias internacionais, vindas sobretudo da Europa, compunham um nicho de mercado 
altamente organizado desde os fins do século 19 , se não antes, em cenário que seria ampliado nos anos seguintes. Já nos primeiros anos do século 20, há registros de companhias líricas italianas chegando ao Brasil com elenco de quase 200 pessoas, entre coristas, bailarinas e músicos - sem mencionar a complexa estrutura cenográfica que as acompanhavam (MORAES, 2014a). Algumas temporadas de apresentações dessas companhias, geralmente realizadas entre maio e outubro, incluíam apresentações em

cidades do Rio Grande do Sul, São Paulo, Rio de Janeiro, Bahia, Pernambuco e Pará (WERNECK, 2012). A pesquisadora Maria João Brilhante (2012) chega a falar de uma “circulação transatlântica do comércio teatral”, que foi especialmente importante para companhias portuguesas de teatro, mas também para companhias italianas de ópera ou companhias espanholas de zarzuela, pode-se acrescentar. No caso dos grupos de teatro de Portugal, as afinidades linguísticas e o apoio da grande comunidade de imigrantes portugueses no Brasil lhes favoreciam. No caso das companhias de ópera da Itália, beneficiava-lhes, sobretudo, a excelência técnica e o prestígio simbólico das óperas italianas.

O crescimento das cidades a partir dos meados do século 19, associado a abolição da escravidão em 1888 e a proclamação da República em 1889, trouxeram, daí em diante, indefinições a respeito das posições sociais de cada indivíduo diante do conjunto da sociedade. No novo regime político instalado pela República, todos eram formalmente livres e iguais, embora, na prática, muitas desigualdades e hierarquias continuassem a existir. De todo modo, no novo contexto, o consumo material e imaterial passou a ser um importante recurso para diferenciação social, quando 
frequentar lugares dotados de prestígio simbólico tornou-se uma importante estratégia para as elites marcarem suas diferenças com relação a outros grupos, delimitando ainda mais claramente as fronteiras de classe que os separavam. Nesses termos, a presença em apresentações de companhias europeias de teatro ou de ópera, tanto quanto em grounds de football, simbolizava a integração a um mundo moderno e civilizado, por meio da exibição pública de um estilo de vida tido e apresentado como requintado. E a sofisticação desses costumes estava justamente em suas ligações e origens europeias. “Cosmopolitismo" seria o nome pelo qual usualmente se descreveria o entusiasmo, pode-se mesmo dizer a quase obsessão, de certos setores da elite brasileira pela cultura europeia naquela época.

A construção do Teatro Amazonas é apenas um exemplo acabado do gosto pelas coisas europeias que afetava as elites brasileiras do período. Construído pelo poder público estadual do Amazonas entre 1881 e 1896, algumas de suas características anteciparam muitos elementos técnicos e simbólicos que se repetiriam depois em várias outras cidades do Brasil. As longas temporadas operísticas com companhias italianas garantidas por subvenções governamentais, ostentavam luxo e requinte, ao mesmo tempo em que exibiam os limites objetivos para as pretensões civilizatórias dos grupos das elites locais. Apresentações de óperas de Ponchicelli por uma companhia lírica italiana eram recebidas sem muita euforia pela população local, que afinal não lotava o teatro, além de exibir comportamentos vistos como inadequados: aplaudia-se fora de hora ou chorava-se de modo inoportuno (DAOU, 2014).

Fenômenos do mesmo tipo também aconteceram em cidades brasileiras menores e distantes dos maiores centros urbanos, embora em proporções menos intensas. Nesses locais, com exceção de grupos de teatro amador, que muitas vezes promoviam 
apresentações em caráter mais ou menos permanente, apesar de toda sorte de dificuldades, o consumo de espetáculos de cinema, circo ou teatro tendia a ser esporádico, marcado pela passagem temporária de companhias ou exibidores ambulantes. Em cidades do interior de Minas Gerais, na transição entre os séculos 19 e 20, companhias itinerantes costumavam se apresentar numa periodicidade que oscilava entre 3 e 6 meses (AMARAL; DIAS, 2017).

Não deixa de ser surpreendente, porém, que exibidores de filmes ou companhias dramáticas, movidas por interesses puramente empresarias, pudessem se deslocar até lugares bastante distantes, como as cidades de Cuiabá e Corumbá, no Mato Grosso, a quase dois mil quilômetros de distância do Rio de Janeiro, a fim de realizar suas apresentações desde os fins do século 19. Em 1890, a companhia teatral do Senhor Velasco, empresário teatral espanhol bastante ativo no cenário dramático brasileiro do período, chegou a Cuiabá para começar apresentações de seu característico repertório de zarzuela e operetas (SANTOS, 2017). Nessa ocasião, quando o sistema de transportes no Brasil ainda era bastante precário, uma viagem entre o Rio de Janeiro e Cuiabá poderia consumir até 4 semanas ou mais, dependendo das condições meteorológicas, além de exigir o emprego de diferentes meios de transportes e a passagem obrigatória por três diferentes países: Uruguai, Argentina e Paraguai. Em todo o caso, é muito provável que a viagem de companhias teatrais até o Mato Grosso envolvesse necessariamente exibições em várias outras cidades no trajeto, o que ampliava tanto o interesse comercial nessas viagens, quanto o raio de ação e influência desses empreendimentos. 
Numa interessante dialética de rupturas e continuidades, diferentes gêneros de entretenimento consagrados a partir de meados do século 20 , muito ou pouco inseridos em redes de comercialização de massas, são herdeiros históricos de formas mais antigas de diversões públicas, ao mesmo tempo em que encerram claramente gradientes de inovação. Uma das principais dessas inovações é a consolidação e disseminação generalizada de uma racionalidade econômica, cujo desenvolvimento se iniciou bem antes de 1960 e evoluiu lentamente ao longo de um período de tempo relativamente longo. Várias modalidades predominantes de diversões públicas do Brasil de outrora, como o teatro ou a música em suas feições modernas, datam desde os meados ou os fins do século 18. Mas é apenas no século 19 que práticas desse tipo vão assumir uma feição cada vez mais comercial. E esta é uma dimensão que acabou por condicionar o desenvolvimento dessas e de várias outras práticas de lazer ao longo de todo o século 20, seja na linguagem, seja nas temáticas, seja nos modos mais gerais de organização. Pois mesmo novas modalidades de lazer surgidas mais recentemente, como o cinema ou os esportes, estariam submetidas a um legado histórico que deita raízes mais antigas: a oferta comercial de lazer para a pura e simples diversão popular, muitas vezes apelando para a predileção por novidades e emoções excitantes. A despeito do que pensem estetas, críticos, intelectuais ou artistas de vanguarda, é assim, grosso modo, que há muito se estrutura boa parte do lazer e do consumo cultural no Brasil. Nesse sentido, mais do que uma revolução abrupta, o desenvolvimento comercial do lazer no Brasil, que também poderíamos chamar tão somente de indústria cultural, foi resultado de uma evolução histórica lenta e paulatina, cujos contornos são apreendidos melhor quando vistos em perspectiva de mais longo prazo. 


\section{REFERÊNCIAS}

ABREU, Marta. $O$ império do divino: festas religiosas e cultura popular no Rio de Janeiro, 1830-1900, Rio de Janeiro: Nova Fronteira, 1999.

ALDEN, Dauril. O período final do Brasil colônia: 1750-1808. In: BETHELL, Leslie (Org.). História da América Latina: de 1870 a 1930. Editora da Universidade de São Paulo / Fundação Alexandre de Gusmão, 2008, 527-592. v. 2.

ALGRANTI, Leila Mezan. Tabernas e botequins: cotidiano e sociabilidades no Rio de Janeiro (1808-1821). Revista do Arquivo Nacional, Rio de Janeiro, p. 25-42, jul./dez. 2011.

AMARAL, Daniel Venâncio de Oliveira; DIAS, Cleber. Nos trilhos do lazer: entretenimento urbano e mercado de diversões em Divinópolis, Minas Gerais, 18901920. Revista de História Regional, Ponta Grossa, v. 22, n. 2, p. 237-261, 2017.

ASSIS, Machado de. Obra completa em quatro volumes. Rio de Janeiro: Nova Aguilar, 2008.

BERNARDET, Jean-Claude. Historiografia clássica do cinema brasileiro. São Paulo: Annablume, 1995.

BOTELHO, Tarcísio R. População e espaço nacional no Brasil do século XIX. Cadernos de História, Belo Horizonte, v. 7, n. 8, p. 67-83, 2005.

BRESCIA, Rosana Marreco. Os teatros públicos na capital das Minas setecentistas: da casa da Ópera de Vila Rica ao Theatro do Ouro Preto. Revista do Instituto de Estudos Brasileiros, São Paulo, n. 52, p. 89-106, set. / mar. 2011.

BRILHANTE, Maria João. Uma aventura ligada pelo oceano: estudar as rotas de teatro entre Portugal e Brasil. In: Angela de Castro Reis e Maria Helena Werneck (Org.). Rotas de teatro entre Portugal e Brasil. Rio de Janeiro: 7 Letras, 2012.

BUDASZ, Rogério. Teatro e música na América Portuguesa: ópera e teatro musical no Brasil (1700-1822). Curitiba: Deartes Universidade Federal do Paraná, 2008.

CAVALCANTI, Nireu. O Rio de Janeiro Setecentista: a vida e a construção da cidade da invenção francesa até a chegada da Corte. Rio de Janeiro: Jorge Zahar, 2004.

COSTA, Emília Viotti da. Da monarquia à república: momentos decisivos. 6 ed. São Paulo: Ed. da Unesp, 1999.

COSTA, Emília Viotti da. Da Senzala à Colônia. São Paulo: Editora Unesp, 1997. 
COUCEIRO, Sylvia Costa. Artes de viver a cidade: conflitos e convivências nos espaços de diversão e prazer do Recife nos anos 1920. Tese (Doutorado em História). Recife: Universidade Federal de Pernambuco, 2003.

DAOU, Ana Maria. A cidade, o teatro e o "paiz das seringueiras": práticas e representações da sociedade amazonense na passagem do século XIX-XX. Rio de Janeiro: Rio Books, 2014.

DEAN, Warren. A economia brasileira, 1870-1930. In: BETHELL, Leslie (Org.). História da América Latina: de 1870 a 1930. São Pàulo: Editora da Universidade de São Paulo / Fundação Alexandre de Gusmão, 2008, p. 659-704. v. 5.

DECCA, Maria Auxiliadora Guzzo. A vida fora das fábricas: cotidiano operário em São Paulo, 1920-1934. São Paulo: Paz e Terra, 1987.

DIAS, Cleber. Epopeias em dias de prazer: uma história do lazer na natureza (17891838). Goiânia: Ed. da UFG, 2013.

Esportes nos confins da civilização: Goiás e Mato Grosso, 1866-1936c. Rio de Janeiro: 7 Letras, 2018.

DUARTE, Regina Horta. Noites circenses: espetáculos de circo e teatro em Minas Gerais no século XIX. Tese (Doutorado em História). Universidade Estadual de Campinas: Campinas, 1993.

FRANCO, Gustavo H. B.; LAGO, Luiz Aranha Corrêa do. O processo econômico: a economia da primeira república, 1889-1930. In: Lilian Moritiz Schwarcz (Coord.). História do Brasil nação: 1808-2010. Rio de Janeiro: Objetiva, 2012, p. 173-238. v. 3.

FURTADO, Celso. Formação econômica do Brasil. 34 ed. São Paulo: Companhia das Letras, 2007.

GOMES, Paulo Augusto. 100 anos de cinema em Belo Horizonte. Varia História, Belo Horizonte, n. 18, p.347-372, set. 1997.

GOMES, Tiago de Melo. Um espelho no palco: identidades sociais e massificação da cultura no teatro de revista dos anos 1920. Campinas: Editora da Unicamp, 2004.

GONÇALVES, Camila Koshiba. Música em 78 rotações: "discos a todos os preços" na São Paulo dos anos 30. São Paulo: Alameda, 2013.

GRAHAM, Richard. Alimentar a cidade: das vendedoras de rua à reforma liberal (Salvador, 1780-1860). São Paulo: Companhia das Letras, 2013.

HALLEWELL, Laurecen. O livro no Brasil: sua história. São Paulo: Ed. da USP, 1985.

HOLANDA, Sérgio Buarque de. A herança colonial - sua desagregação. In: HOLANDA, Sérgio Buarque de (Org.). História geral da civilização brasileira. São Paulo: Difel, t. II, vol. 1, 1983. 
INSTITUTO NACIONAL DE ESTATÍSTICA. Anuário Estatístico do Brasil. Ano II, Rio de Janeiro: Typographia do Departamento de Estatística e Publicidade, 1936.

LEOPOLDI, Maria Antonieta P. A economia política do primeiro governo Vargas (1930-1945): a política econômica em tempos de turbulência. In: FERREIRA, Jorge; DELGADO, Lucilia de Almeida Neves (Org.). O Brasil republicano. Rio de Janeiro, Civilização Brasileira, 2003, p. 241-286. v. 2.

LUCCOCK, John. Notas sôbre o Rio-de-Janeiro e partes meridionais do Brasil: tomadas durante uma estada de dez anos nesse país, de 1808 a 1818. São Paulo: Martins, 1942.

MELLO, João Manuel Cardoso de; NOVAIS, Fernando A. Capitalismo tardio e sociabilidade moderna. In: Lilian Moritz Schwarcz (Org.). História da vida privada no Brasil: contrastes da intimidade contemporânea. v. 4. São Paulo: Companhia das Letras, 1998, p. 559-658. 4. 4

MELO, Victor Andrade de (Org.). Pois temos touros: touradas no Brasil do século XIX. Rio de Janeiro: 7 Letras, 2017.

. Os sports e as cidades brasileiras: transição dos séculos 19 e 20. Rio de Janeiro, Apicuri, 2010.

- Mudanças nos padrões de sociabilidade e diversão: o jogo da bola no Rio de Janeiro (séculos XVIII e XIX). História, São Paulo, v. 35, n. 105, p. 1-23, 2016.

. Cidadesportiva: primórdios do esporte no Rio de Janeiro. Rio de Janeiro: Relume-Dumará / Faperj, 2001.

MONTEIRO, Maurício. A construção do gosto: música e sociedade na Corte do Rio de Janeiro, 1808-1821. Rio de Janeiro: Ateliê, 2008.

MORAES, Julio Lucchesi. São Paulo, capital artística: a cafeicultura e as artes na belle époque (1906-1922). São Paulo: Azougue, 2014b.

- Sociedades culturais, sociedades anônimas: distinção e massificação na economia da cultura brasileira (Rio de Janeiro e São Paulo, 1890-1922). Tese (Doutorado em História Econômica). São Paulo: Universidade de São Paulo, 2014a.

ORTIZ, Renato. A moderna tradição brasileira: cultura brasileira e indústria cultural. 5. ed. São Paulo: Brasiliense, 1994.

PADILHA, Marcia. A cidade como espetáculo: publicidade e vida urbana na São Paulo dos anos 20. São Paulo: Annablume, 2001.

PINHEIRO, Paulo Sérgio. O proletariado industrial na Primeira República. In: Boris Fausto (Org.). História geral da civilização brasileira: O Brasil republicano, tomo III, v. 9. Rio de Janeiro: Bertrand Brasil, 2006. 
PRADO, Décio de Almeida. As raízes do teatro brasileiro. In: FARIA, João Roberto (Dir). História do teatro brasileiro. São Paulo: Perspectiva / Edições Sesc SP, 2012, p. 21-65.

PRADO, Luiz Carlos Delorme; EARP, Fábio Sá. O "milagre" brasileiro: crescimento acelerado, integração internacional e concentração de renda (1967-1973). In: Jorge Ferreira e Lucilia de Almeida Neves Delgado (Org.). O Brasil republicano. v. 4. Rio de Janeiro: Civilização Brasileira, 2003, 207-242.

PREFEITURA DO DISTRITO FEDERAL. Anuário Estatístico do Distrito Federal. Ano X, vol. IV. Rio de Janeiro: Secretaria de Geografia e Estatística, 1946.

SANTOS, Marcela Ariete dos. O teatro em Mato Grosso (1889-1930). Dissertação (Mestrado em Estudos do Lazer). Belo Horizonte: Universidade Federal de Minas Gerais, 2017.

SILVA, Erminia. Circo-teatro: Benjamin de Oliveira e a teatralidade circense no Brasil. São Paulo: Altana, 2007.

SILVA, Andrée Mansuy-Diniz. Portugal e o Brasil: a reorganização do Império, 17501808. In: BETHELL, Leslie (Org.). História da América Latina: de 1870 a 1930. v. I. Editora da Universidade de São Paulo / Fundação Alexandre de Gusmão, 2008, p. 477518.

SINGER, Ben. Modernidade, hiperestímulo e o início do sensacionalismo popular. In: CHARNEY, Leo; SCHWARTZ, Vanessa. O cinema e a invenção da vida moderna. 2 ed. rev. São Paulo: Cosac \& Naif, 2004, p. 95-126.

SODRÉ, Nelson Werneck. História da imprensa no Brasil. 4 ed. Rio de Janeiro: Mauad, 1999.

SOUZA NETO, Georgino Jorge de; SILVA, Sílvio Ricardo da. O advento do lazer em Belo Horizonte ou das "festas e diversões": um estudo dos hábitos de divertimento na 'cidade moderna' a partir do Minas Geraes. Licere, Belo Horizonte, v. 12, n. 2, jun./2009.

SOUZA, José Inácio de Melo. Imagens do passado: São Paulo e Rio de Janeiro nos primórdios do cinema. São Paulo: Senac São Paulo, 2003.

SOUZA, Silvia Cristina Martins de. As noites do Ginásio: teatro e tensões culturais na Corte (1832-1868). Campinas: Editora da Unicamp / Cecult, 2002.

TINHORÃO, José Ramos. História social da música popular brasileira. São Paulo: Editora 34, 1998.

WERNECK, Maria Helena. A solução dos transatlânticos. In: Angela de Castro Reis e Maria Helena Werneck (Org.). Rotas de teatro entre Portugal e Brasil. Rio de Janeiro: 7 Letras, 2012, p. 19-32. 


\section{Endereço do Autor:}

Cleber Dias

EEFFTO/UFMG

Av. Antônio Carlos 6627, Pampulha

Belo Horizonte - MG - 30.270-901

Endereço Eletrônico: cleberdiasufmg@gmail.com 